\title{
Competence development of entrepreneurs in innovative horticulture.
}

\author{
Martin Mulder ${ }^{1}$, Thomas Lans ${ }^{2}$, Jos Verstegen ${ }^{3}$, Harm Biemans $^{4}$ and Ypie Meijer ${ }^{5}$
}

Wageningen University, the Netherlands ${ }^{6}$

${ }^{1}$ Head Chair Group of Education and Competence Studies (ECS)

Wageningen University

Social Sciences Group - bode 68

PO Box 8130

NL-6700 EW Wageningen

Netherlands

Phone: + 313174841 81; Fax: + 31317484573

Mobile: + 31620677340

Email: martin.mulder@wur.nl

Internet: www.ecs.wur.nl

Internet: www.mmulder.nl

${ }^{2}$ Assistant professor - thomas.lans@wur.nl

${ }^{3}$ Assistant professor - harm.biemans@wur.nl

${ }^{4}$ Researcher - jos.verstegen@wur.nl

${ }^{5}$ Past trainee at ECS

${ }^{6}$ We thank AHON (i.e. LTO Groeiservice) and the entrepreneurs who participated in this study for their assistance and their openness to share opinions, experiences and ideas about learning and entrepreneurship.

\section{Structured abstract}

Purpose. To study learning of entrepreneurs in authentic learning environments. The research questions are: 1 . How do entrepreneurs assess their compentencies, and how do employees and external consultants assess the compentencies of these entrepreneurs? 2. What are the competence strengths and weaknesses of entrepreneurs? 3. What are the learning activities that entrepreneurs perform?

Methodology/Approach. Ten small business owners participated in a self-assessment and an assessment by employees and external consultants. Follow-up interviews elicited work-related learning activities. The interviews were transcribed. Descriptive statistics, t-tests and correlation tests, and a qualitative analysis of interview transcriptions were performed.

Findings. 1. Competencies are being rated differently. Competence assessment is a potentially powerful learning source. 2 . The top competence strength is having a learning orientation. 3. Ninety-nine learning activities were found embedded in the innovative work processes of the entrepreneurs. The top three learning activities were reflection, observation and experimentation.

Research limitations/implications. The study is based on only ten entrepreneurs. Research is planned with larger numbers of subjects.

Practical implications. Competence assessment needs to be provided for entrepreneurs in the sector as a tool for deeper self-reflection, and further performance improvement.

Originality/value of paper. Much research on skills development and workplace learning is about employees in large organisations. However, employers in small and medium-sized companies are also an interesting professional group to study, since they create working and 
learning places for employees. Not much is know about their competence development. This study addresses that target group.

\section{Keywords}

Competence, entrepreneurship, small and medium-sized companies, learning, assessment, innovation

\section{Categorisation of the paper:}

Research paper 


\section{Introduction}

Much research on skills development and workplace learning is about employees, for instance nurses (Berings et al., 2006), policemen (Doornbos, 2006) and low skilled workers

(Raemdonck, 2005). However, employers are also an interesting professional group to study, since they create working and learning places for employees.

In this contribution a study on practical learning of entrepreneurs is reported. This study is part of a larger program on competence development in organisations, and the support of learning of entrepreneurs.

The context in which this study is situated is one specific, innovative branch in the Dutch agri-food cluster, greenhouse horticulture. General characteristics of this branch are that it is capital and knowledge intensive and highly innovative. Genomics, agro-ecosystems, bio(nano)technology, ICT-supported climate control, pharmacy, energy reduction, electronic trade, and advanced packaging and logistics all have their influence on firm developments. As Hulsink (2005) put it: there is a trend from farming knowledge and communicating this, to knowledge farming. Other trends are product diversification, internationalization, shortening distribution chains, and collaboration at cluster level. Firm sizes increase rapidly and various firms, for instance in the plant breeding and crop protection area, have their own line of research.

Socio-economic developments in greenhouse horticulture are monitored by LEI Wageningen UR, the leading institute in the Netherlands on agricultural economic research. This institute maintains a Farm Accountancy Data Network providing a comprehensive database of information on developments and trends in agriculture. Typically, profit margins are small and therefore, small changes in yields (e.g. by crop diseases) or in market prices (e.g. by currency fluctuations) can have a high impact on family income. For the same reason, variation in family income among firms with approximately the same size and structure is large. This stresses the importance of having highly competent entrepreneurs in the firms.

Entrepreneurs are facing various dilemmas when coping with regional, national and international developments and competition. They have to balance between craftsmanship and an opportunistic orientation of entrepreneurship, depending on their competencies, motivations and perceptions about their business (Smith and Miner, 1983). According to Chandler and Jansen (1992) three distinctive roles can be assumed by the owner of a firm, namely, an entrepreneurial role, a managerial role and a technical/craftsman role. Enterprises that grow get more employees, which calls for more attention to personnel management, an area traditionally not very much explored by horticultural growers. Other dilemmas are related to growth of the enterprise and the lifestyle of the entrepreneur. Growth and internationalisation require large investments and changes in working patterns, from less physical labour activities in the greenhouse to more mental work in offices, holding meetings and more travelling abroad. One could say that where the focus in agriculture in the past was predominantly on the technical/craftsman role, the managerial and entrepreneurial role has gained importance.

What exactly characterises an 'entrepreneur' in greenhouse horticulture? Various definitions revolve around entrepreneurs and entrepreneurship. The dominant view on entrepreneurship put forward by many authors is that it represents the domain of discovering and pursuing opportunities. Although not necessarily consecutive, the following phases are mentioned 
many times in the literature: 1 . sensing (sensitivity for new developments), 2. recognition (seeing a fit between opportunity and possibility, and the further development of a business plan), and 3. evaluation (redesign, formative or summative). Examples of outputs of opportunities are new products, new services, new markets, new inputs, new production methods and new methods of organization (Shane, 2003). Important in this view is that it is not so much important who an entrepreneur is, but what an entrepreneur does (Gartner, 1988).

Accordingly, we see entrepreneurship as a specific profession. Knowledge and skills needed for successful professional performance has been represented widely as professional competence. Recent literature focuses more and more on the holistic interpretation of the concept of competence (Biemans et al, 2004; Wesselink et al., in press). The holistic notion of competence does not reduce competence to one cognitive dimension, trait, knowledge, skill or personal characteristic (which has proven to be unsuccessful in entrepreneurship literature). It rather focuses on the ability to successfully meet complex demands in a particular context (which includes the mobilization of knowledge, skill as well as social and behavioural components such as attitudes) (Mulder, 2001; Mulder and Weigel, 2006; Weigel and Mulder, 2006).

The research questions of this study are the following:

1. How do entrepreneurs evaluate their own mastery of competencies that are relevant for entrepreneurship? How do internal co-workers (employees) evaluate the mastery of these competencies by their entrepreneurs (directors)? How do external consultants evaluate this mastery by their client entrepreneurs?

2. What are the present competence strengths and weaknesses of entrepreneurs as perceived by entrepreneurs themselves, their co-workers and consultants?

3. What are the learning activities that entrepreneurs perform and how are they related to the entrepreneurial competencies needed?

\section{Data and methods}

For this study entrepreneurs were selected who participated in the national committees of the Agriculture and Horticulture Organization of the Netherlands (AHON) (LTO) for (agricultural) products. There are about twenty of these committees (such as for cucumbers, peppers, tomatoes, pot plants, cut flowers) and there are about 200 members of these committees in total. Committee members are active in the national context of defending interests of the sector, they are known as being innovative in farming, professional in sector government, communicative, supporters of the national sector interests, international in orientation, politically interested, well-informed about the Common Agricultural Policy coming from Brussels, pro-active and committed to the sector.

The study consisted of two phases; in the first phase quantitative data of 10 of the 200 AHON small business owners who were willing to participate was obtained by means of a competence assessment. The group of ten entrepreneurs appeared to be representative for the total group of 200. There was a mix in age of the entrepreneur and geographical location of the firm, and the companies they own are quite representative in terms of firm size. Triangulation of the data was used by conducting a (1) self-assessment, (2) an internal assessment (employee or other co-worker in the company) and (3) an external assessment (external consultant) procedure. Multi-rater assessments can be powerful instruments to assess competencies. Not only from a practical point of view (providing the small business owner with potentional areas for learning and development), but also from a methodological point of 
view. The entrepreneurs were asked which competencies they had developed during the last five years and which competencies they saw possibilities for further development in the near future. The list of competencies was based on the set provided by Man et al. (2002), which was worked out in detail by Lans et al. (2005). The internal and external assessors were asked to rate the entrepreneur on the same set of competencies for both the past and the future. Two five-point (Likert) scales were used as answering categories; ranging from 1 'to a very limited extent' to 5 'a very high extent'.

The second phase of this study consisted of a follow-up, in-depth, semi-structured interview. The data of the first phase was taken as a starting point. The follow-up personal interviews started with three basic questions about the entrepreneurs' opinion on the outcome: 1) are the results recognisable, 2) what are the most surprising outcomes, and 3) what are concrete possibilities for development? Subsequently, the interviews were used to elicit work-related learning activities that contributed specifically to the development of entrepreneurial competencies. The method adopted for eliciting learning in the workplace was based on the critical incident technique, originally set forward by Flanagan (1954). It is a methodology that has been employed in a wide range of settings; it has particular relevance in the field of learning but also specifically in the field of entrepreneurship (Cope and Watts, 2000). Billett (1994) developed the CIT particularly for eliciting learning in the workplace.

Since we were interested in the learning processes concerned, especially the development of entrepreneurial competence, the processes of identifying and pursuing opportunities (including the introduction and evaluation of it) was central in the conducted interviews. Therefore the interview focussed on critical incidents that were specially connected to a pursued opportunity within the business. Hence, the starting point of the interviews were e.g. the introduction of new goods, services, ways of organizing, markets or processes that previously had not exist (Shane, 2003). Within the interviews the following questioning structure was adopted. Interviewees had to recall an incident where they had success with pursuing an opportunity, the follow-up questions were: 1 . Where did the idea for this opportunity come from? 2. What went well and what went wrong in further pursuit of this opportunity? 3. Looking back, who or what would they have needed assistance from to be more successful in the future? 4 . What were the final consequences for the enterprise? Each interview was audio-taped and subsequently transcribed.

Regarding the data-analysis: descriptive statistics, a t-test and correlation test, and a qualitative analysis of interview transcriptions were performed. For the qualitative analysis of the interview transcriptions, the analysis method of Doornbos $(2006,45)$ was used. She distinguished adult learner activities to define entrepreneurial learning activities.

In this contribution the data relating to the perceived competencies and the interviews is reported.

\section{Results}

In this results section, first the evaluation of competencies of entrepreneurs, co-workers and consultants is presented. Next, the competence strengths and development challenges are described. After that the learning activities of entrepreneurs are described, and the three top learning activities are further elaborated by depicting short portraits of the entrepreneurial learning activities concerned. Finally the learning activities are linked to competencies. 


\section{Evaluation of competencies of entrepreneurs, co-workers and consultants}

Table 1 presents the average assessment scores (and standard deviations) of the entrepreneurs themselves, and those of the co-workers and consultants (who assessed the entrepreneurs).

Take in Table 1.

The average self-assessment score of the entrepreneurs is 3.10. The averages within the selfassessment scores range from 2.59 to 3.73. On average, the entrepreneurs rate themselves lower than the rating attributed to them by their co-workers and consultants. The average scores by co-workers and consultants are 3.36 and 3.44. The average score by co-workers varies from 2.86 to 4.09 and those by the consultants from 2.77 to 4.09 too.

For the average scores of the entrepreneurs themselves, the co-workers and the consultants, a simple t-test was performed. The differences between the means appeared to be significantly different (t-values for the means are 30.77, 31.39 and 28.48 with all significance levels at $0.000)$.

Comparable results are found with a correlation analysis of the assessment data of the entrepreneurs, co-workers and consultants, calculating the Spearman correlation coefficient.

Take in Table 2.

There are low correlations between the competency self-assessment and the assessment of coworkers and consultants, and between co-workers and consultants. None of the selfassessment scores and scores by co-workers varied systematically. The maximum correlation coefficient was .326, the lowest .045. The average correlation was .097. Three of the selfassessment scores and scores by consultants were statistically significant for entrepreneur 1,3 and 6. The correlations varied from .590 to .068. The average correlation was -.021 . One of the correlations between the scores by co-workers and consultants was statistically significant, which was the correlation for entrepreneur 5 (.556). The minimum correlation here was -.004 , and the average correlation .100 .

\section{Competence strengths and development challenges}

The top three and bottom three competencies of the entrepreneurs (as measured by the average assessments of the entrepreneur, co-workers and consultants) are scattered (see Table 3). Learning orientation and self management are the first two highest scoring competencies of the entrepreneur while international orientation and human resource management are the two lowest ranked competencies.

Take in Table 3.

\section{Learning activities of entrepreneurs}

As mentioned before, personal onsite in-depth interviews with the entrepreneurs were conducted after the multi-rater assessments, .The interviews were transcribed and the transcriptions were analysed. Many learning activities were found in the study. They were categorised using the scheme of Doornbos (op cit). The categories thus found are presented in 
Table 4. First the type of learning activity is mentioned, next literal examples are given from quotes of the interviews.

Take in Table 4.

Next, the learning activities in the transcriptions were coded according to the categories distinguished. In total 106 learning activities were recorded in the interview transcriptions. In Table 5 the frequencies and percentages of the learning activities mentioned in the interviews are presented.

Take in Table 5.

As can be seen, reflection, observation and experimentation are the three learning activities that are reported most frequently. Acquiring knowledge in training, replication and holding on to a personal vision are least frequently cited; together they account for only $10 \%$ of the total of learning activities. Training is at the bottom of the list, mentioned only three times.

What the top three learning activities mean in reality is described in the following learning portraits of three entrepreneurs (names are fictitious). These activities account for nearly half of the number of the learning activities mentioned.

Rudy - reflects on practice

When Rudy is asked whether he knows how his customer or suppliers think about him, he answers positively. This especially holds for his large buyers with whom he has regular conversations about what went well and what went wrong:

'I need that kind of feedback. I do not want the situation where some buyers come and say: we will leave as a client because we think you are not performing well enough. I mean, that is of course a situation that is not desirable, you should have known their complaints already three months earlier'.

Expanding your firm means that tasks change and that there is less time spent with physical labour in the greenhouse. Rudy agrees with this and he says that it depends on how you want to organise your work. He has learned to give some work away. For instance, his wife does the bookkeeping now:

'I sometimes get phone calls from a supplier about a certain invoice. I used to think that I had to answer all these questions, just because I am the boss, and that I should know everything. I have learned not to pretend that I know everything. I just reply that I don't know the answer, but refer him to someone in the company who has the right information'.

It can, however, be threatening for some entrepreneurs because they think that if they do not know the answers they are not true entrepreneurs. Knowing yourself, your strengths and weaknesses, is very important in this perspective. Rudy confirms this:

'I agree, but self management is difficult, and one can only develop this by thinking about these kinds of situations. I know for instance that three or four years ago this was very difficult for me. I always did everything by myself. Until one of my internship students mentioned to me that a lot of business owners have blind spots, the issue of 'being dulled by routine'. That incident made me think. At a certain moment I got some critiques of my staff on the way I performed a certain task. I remember that I replied that I agreed with them. So we discussed this point and eventually I let other people take over this specific task'. 
Olaf - he who observes

Important developments in a business such as when and how to make the decision to expand, Olaf lie within the history of the company. One starts small and becomes larger and larger step-by-step.

Olaf is involved in a national network of entrepreneurs in his specific field:

'I observe them and get convinced that I am doing well and that we do not have to invest heavily in my business'.

He observes his colleagues in this national network and does not want to be out of step of them. That is what he always wants:

'Yes, that is one of the reasons of participating in that kind of networks, beside economic incentives. Every person wants to drive, in principle, the same kind of car. As a company I want to be among the best of the Netherlands'.

Olaf's role models are his colleagues in his direct region and comparatively he is doing quite well, he says:

'But if I look a bit further, for instance in the other provinces of the Netherlands, I see that since three to four years now, some companies go faster in their development than mine. I know exactly where I stand. The speed of development is enormously these days. In the old days you could keep up quite easily'.

Eric - who likes experiments

Eric has a strong drive to create new business. It is interesting to see how he establishes new things and how he brings his ideas about. He started approximately ten years ago as an employee in horticulture and thought that running a business was something that he could also do:

'That's when I started growing tulips by myself, from zero to 12 billion. Well, the first year went reasonably well, but the second year was terrible, I did not have any experience in conservation methods of those tulips. On top of that, I was accused of hiring illegal employees, my business went bankrupt and I ended up with a debt of more than one and a half billion Euros. So I stopped, but started again; this time I tried it under my girlfriend's name. And because I do not like small, I managed to grow fast again in the next five years and became one of largest producers in Netherlands. I was also one of the first that switched to a complete new production method'.

It is interesting to see how Eric recognizes problems and easily shifts from one solution to another. For example he decided to introduce a different means of transportation in the company in order to create more space. After he had introduced this new system it appeared that it did not match the production line in the company very well:

\footnotetext{
'This generated the next idea to also change our production methods. Our advisor tipped us with a new production method. So I experimented with this new production method for two years; in this case I wanted be sure. But after these two years we decided rather quickly that the whole business should be adapted to this new method. We also got the idea to grow a complete new cultivar. So we also decided to experiment with that new cultivar a couple of years. And now I can say that I am back in the top of the producers in my field. That is the way I am, big is beautiful'.
}

\section{Linking learning activities to competencies}


The learning activities are grouped under the competence cluster by interpreting the meaning of the learning activity in the context of its use. The results of this linkage are presented in Table 6.

Take in Table 6.

In Table 6 we see that $26 \%$ of the learning activities can be positioned in the strategic competence cluster, $20 \%$ in the opportunity cluster, $20 \%$ in the organising competence cluster and $18 \%$ in the technical-occupational cluster. The conceptual and commitment competence clusters account for only $7 \%$ of the learning activities while $9 \%$ of the learning activities fit into the relational competence cluster.

\section{Conclusions and discussion}

In this conclusions and discussion section, the three research questions will be addressed and some issues for reflection will be presented.

Regarding the first research question our answer is: competencies are being rated differently. This is consistent with the literature on multi-rater feedback. It was surprising however to see that entrepreneurs evaluate their own mastery of competence lower than internal co-workers and external consultants do. The low correlations between competency assessments of the entrepreneurs by co-workers and consultants support the inclusion of multiple raters in the assessment process. They apparently have different perceptions of the competencies of the entrepreneur. It emphasis the importance that competence should not be seen as an objective measure, but should be viewed as a socially constructed object. Self-assessment and the comparison of the results of this with competency evaluations of internal co-workers and external consultants is a potentially powerful learning source.

As to the second question, the top competence strength as rated by the entrepreneurs, coworkers and consultants, is having a learning orientation. Many entrepreneurs are permanently learning from their activities, that was also the observation in the interviews. Entrepreneurship appears to be a very rich, authentic and powerful learning context. As stated, many entrepreneurs are also good in self-management. However, in terms of international orientation and human resource management, there is much room for improvement. Entrepreneurs who want to expand their business and go beyond the regional and national borders for trade, and those who want to increase the number of their employees will have to strengthen their competence in these fields. Since firm expansion is a dominant trend in greenhouse horticulture, those entrepreneurs who want to stay in business have to give more attention to human resources issues, especially from the perspective of corporate social responsibility.

Regarding the third research question: the first observation we make here is that a large amount of learning takes place in innovative entrepreneurial contexts: ninety-nine learning activities were found embedded in the innovative work processes of the entrepreneurs. In other business processes, learning may be less prominent (Guile, 2002). The top three learning activities were reflection, observation and experimentation, which are linked to the three major general activities regarding the implementation of innovations: observing what is going on in the environment (e.g. market, actions of colleagues and competitors), 
experimenting with new initiatives such as firm expansion, observing the results, and reflecting on these results to see what was and was not successful

Much learning is linked to the decision-making process of entrepreneurs. In the process, they focus on problems that arise aiming to solve them as soon as possible to avoid the detrimental effects they can have on the firm if not addressed quickly.

Much learning also takes place by looking at examples. Such vicarious learning (Shane, 2003) is quite visible. There is also a need for role models. When entrepreneurs see a successful innovation introduced by one of their colleagues they tend to imitate. However this brings the risk of implementing the innovation too late to get 'early-mover' advantages. But this also allows entrepreneurs to learn from the mistakes of others. At the same time, mistakes are context-specific, and may not apply to their own firm context. Nevertheless, it would be worthwhile to analyse the mistakes, make them anonymous for confidentiality reasons, and evaluate the usefulness of the cases for sharing experiences with other entrepreneurs. It also may help to collect cases from other sectors, since then there will be little competitive forces impeding the exchange of information about mistakes.

What is the relationship between competencies and learning activities? Most learning activities are related to strategic, opportunity, organising, and the technical-occupational competence clusters. Less learning activities are linked to the conceptual, commitment and relational competence clusters.

Looking back on the whole study, we think it is important for entrepreneurs to evaluate their own professional behaviour in relation to innovation and performance improvement. They are not always doing this to the extent that would be beneficial for their business. Multi-rater competence assessment as practiced in this study, including the mapping of their learning activities within the competence clusters too, appears to be a powerful tool to make entrepreneurs aware of their professional competences. Direct and concrete feedback on their competencies can serve as a combined evaluation from inside and outside the company. It can help to solve the paradox in which entrepreneurs find themselves in innovative practices. On the one hand they need to look outwards and participate in external networks to get innovative ideas, but on the other hand they need to focus inwards, to prevent competitors from copying innovations (Gielen, Hoeve \& Nieuwenhuis 2003).

Competence assessment may lead to deeper self-reflection, and further performance improvement. An important condition for this is of course the willingness to look at oneself, to be open to feedback from others and to be honest towards oneself in terms of identifying areas of professional improvement. During the interviews it was surprising to note that the entrepreneurs were quite open to the assessment process, the discussion of the results, and the reflection about this. It was also noteworthy that entrepreneurs spoke freely about their mistakes.

Our final conclusion is that much, rich, situated (Billet, 1996) and divers practical learning is taking place in the daily work of the entrepreneurs we studied. They use these learning experiences to further develop their entrepreneurial competence. The experiences tend to be more intense if the stakes (gains and losses) are higher.

This observation leads us to suggest another type of workplace learning. Simons, Van der Linden and Duffy (2000) distinguished the guided learning, experiential learning and action 
learning varieties. Simons et al (2000) suggested the following three metaphors (cf Romiszowski, 1981): travelling, trekking and exploring. We suggest to add entrepreneurial learning as climbing. Entrepreneurs who want to reach the top must take big steps upwards, with the risk of falling down. Especially with steep rocks and bad weather conditions, they have to know very well what their personal constraints are, and if not, they need good guides to point these out or to learn them to how to deal with these constraints in order to reach the ultimate goal.

\section{References}

Berings, M. G. M. C., Gelissen, J. P. T. M. and Poell, R. F. (2006), "What and how do nurses learn on the job? Similarities and differences among nurses in on-the-job learning”, in S. Sambrook and Stewart, J. (Eds.), HRD in the public sector: The case of health and social care, Routledge, London.

Biemans, H., Nieuwenhuis, L., Poell, R., Mulder, M. and Wesselink, R. (2004), "Competence-based VET in The Netherlands: backgrounds and pitfalls", Journal of Vocational Education and Training, Vol 56, No 4, pp. 523-538.

Billett S., (1994), Situated Learning - a workplace experience, Australian Journal of Adult and Community Education, 34 (2), 112-130.

Billet, S. (1996), "Situated learning: bridging sociocultural and cognitive theorising', Learning and Instruction, Vol 6, No 3, pp. 263-280.

Chandler, G.N. and Jansen, E. (1992), “The founder's self-assessed competence and venture performance”, Journal of Business Venturing, Vol 7, No 3, pp. 223-236.

Cope, J. and Watts, G. (2000), Learning by doing: an exploration of experience, critical incidents and reflection in entrepreneurial learning, International Journal of Entrepreneurial Behaviour and Research, 6, 3, 104-124.

Doornbos, A. (2006), Work-related Learning at the Dutch Police Force. Doctoral dissertation, Politieacademie, Apeldoorn.

Flanagan, J.C., (1954), The critical incident technique, Psychological Bulletin, 51,.327-355.

Gartner, W.B. (1989), “'Who is an entrepreneur?' is the wrong question”, Entrepreneurship theory \& practice, Vol 13, No 4, pp. 47-68.

Gielen, P.M., Hoeve, A. and Nieuwenhuis, A.F.M. (2003), "Learning entrepreneurs as experts”, Journal of Agricultural Education and Extension, Vol 9, No 3.

Guile, D. (2002), "Skill and Work Experience in the European Knowledge Economy”, Journal of Education and Work, Vol 15, No 3, pp. 251 - 276.

Hulsink, W. (2005), From farming knowledge to knowledge farming, Inaugural address, Wageningen University, Wageningen.

Lans, T., Bergevoet, R., Mulder, M. and Van Woerkum, C. (2005), "Identification and measurement of competences of entrepreneurs in agribusiness", in Batterink, M., Cijsouw, R., Ehrenhard, M., Moonen, H. and Terlouw, P. (Eds.). Selected papers from the 8th Ph.D. Conference on Business Economics, Management and Organization Science, PREBEM/NOBEM, Enschede, pp. 81-95.

Man, T. W. Y., Lau, T. and Chan, K. F. (2002), "The competitiveness of small and medium enterprises - A conceptualization with focus on entrepreneurial competences”, Journal of Business Venturing, Vol 17, No 2, pp. 123-142.

Mulder, M. (2001), “Competence development - some background thoughts”, The journal of agricultural education and extension, Vol 7, No 4, pp. 147-158.

Mulder, M. and Weigel, T. (2006), A critical analysis of the use of the competence concept in the development of vocational education and training in selected countries, 
Wageningen University, chair group of Education and Competence Studies, Wageningen.

Raemdonck, I. (2003), Self-directed learning in perspective of the lower educated workers' career development. Paper presented at The Third International Conference 'Researching Work and Learning', Tampere, Finland.

Romiszowski, A.J. (1980), Designing instructional systems, Kogan Page, London.

Shane, S. (2003), A general theory of entrepreneurship. The individual-opportunity nexus, Edward Elgar, Cheltenham.

Simons, P.R.J., Van der Linden, J. \& Duffy, T. (Eds.) (2000), New learning, Kluwer Academic Publishers, Dordrecht.

Smith, N.R. \& J.B. Miner (1983), Type of entrepreneur, type of firm and managerial motivation: implications for life cycle theory, Strategic Management Journal, 4, 325340.

Weigel, T. and Mulder, M. (2006), A review of use of the competence concept in the development of vocational education and training in selected countries, Wageningen University, chair group of Education and Competence Studies, Wageningen.

Wesselink, R., Biemans, H.J.A. and Mulder, M. (in press). "Competence-based VET as seen by Dutch researchers”, European Journal of Vocational Training. 
Table 1. Average assessment scores and standard deviations on the competencies of the entrepreneurs by themselves, co-workers and consultants

\begin{tabular}{|c|l|l|l|l|c|l|}
\hline & $\begin{array}{l}\text { Av Score } \\
\text { Eelf } \\
\text { Essessment }\end{array}$ & Sd & $\begin{array}{l}\text { Av Score } \\
\text { assessment by } \\
\text { co-worker }\end{array}$ & Sd & $\begin{array}{l}\text { Av Score } \\
\text { assessment by } \\
\text { consultant }\end{array}$ & Sd \\
\hline 1 & 3.36 & 1.26 & 3.50 & .60 & 3.41 & .91 \\
\hline 2 & 3.18 & .73 & 3.23 & .69 & 3.19 & .81 \\
\hline 3 & 2.59 & .67 & 3.27 & .88 & 3.64 & .66 \\
\hline 4 & 3.27 & .70 & 3.55 & .74 & 3.50 & .74 \\
\hline 5 & 2.91 & .68 & 3.05 & .38 & 2.77 & .92 \\
\hline 6 & 2.86 & .83 & 3.41 & 1.10 & 3.00 & .69 \\
\hline 7 & 2.86 & 1.25 & 3.50 & .51 & 3.38 & .92 \\
\hline 8 & 3.05 & .65 & 4.09 & .68 & 3.73 & .46 \\
\hline 9 & 3.73 & .88 & 2.86 & .89 & 3.68 & .48 \\
\hline 10 & 3.14 & .83 & 3.14 & .56 & 4.09 & .29 \\
\hline Average & $\mathbf{3 . 1 0}$ & $\mathbf{0 . 8 5}$ & $\mathbf{3 . 3 6}$ & $\mathbf{. 7 0}$ & $\mathbf{3 . 4 4}$ &. $\mathbf{6 9}$ \\
\hline
\end{tabular}


Table 2. Spearman correlation coefficients and significance levels for the relationships between the competence assessments of the entrepreneur (Self) and co-worker and consultant, and of co-worker and consultant

\begin{tabular}{|c|l|l|c|c|c|c|}
\hline Entrepreneur & $\begin{array}{l}\mathbf{R}_{\mathbf{s}} \text { Self-Co- } \\
\text { worker }\end{array}$ & $\begin{array}{l}\text { p-value } \\
\text { (2-tailed) }\end{array}$ & $\begin{array}{l}\mathbf{R}_{\mathbf{s}} \text { Self- } \\
\text { consultant }\end{array}$ & $\begin{array}{l}\text { p-value } \\
\text { (2-tailed) }\end{array}$ & $\begin{array}{l}\mathbf{R}_{\mathbf{s}} \text { Co- } \\
\text { worker- } \\
\text { consultant }\end{array}$ & $\begin{array}{l}\text { p-value } \\
\text { (2-tailed) }\end{array}$ \\
\hline 1 & -.143 & .526 & $.590\left(^{* *}\right)$ & .004 & .147 & .514 \\
\hline 2 & .137 & .542 & .427 & .054 & .351 & .119 \\
\hline 3 & .225 & .313 & $.429\left(^{*}\right)$ & .046 & .042 & .854 \\
\hline 4 & .326 & .139 & .068 & .765 & -.004 & .985 \\
\hline 5 & .219 & .327 & .245 & .272 & $.556\left(^{* *}\right)$ & .007 \\
\hline 6 & -.080 & .722 & $.493\left(^{*}\right)$ & .020 & .204 & .361 \\
\hline 7 & .045 & .844 & -.275 & .228 & .075 & .748 \\
\hline 8 & .069 & .761 & .192 & .393 & .232 & .299 \\
\hline 9 & -.050 & .825 & -.377 & .084 & .081 & .720 \\
\hline 10 & .225 & .313 & .377 & .084 & -.091 & .686 \\
\hline Average & $\mathbf{0 . 0 9 7}$ & $\mathbf{0 . 5 3 1}$ & $\mathbf{- 0 . 0 2 1}$ & $\mathbf{0 . 1 9 5}$ & $\mathbf{0 . 1 0 0}$ & $\mathbf{0 . 5 2 9}$ \\
\hline
\end{tabular}


Table 3. Strengths and weaknesses of the entrepreneurs based on average scores of multi-ratings of competencies (the highest and lowest three averages are listed as + and -), and number of competencies on which the entrepreneurs score highest and lowest.

\begin{tabular}{|l|l|l|l|l|l|l|l|l|l|l|l|l|}
\hline \multicolumn{1}{|c|}{ Entrepreneurs } & $\mathbf{1}$ & $\mathbf{2}$ & $\mathbf{3}$ & $\mathbf{4}$ & $\mathbf{5}$ & $\mathbf{6}$ & $\mathbf{7}$ & $\mathbf{8}$ & $\mathbf{9}$ & $\mathbf{1 0}$ & & \\
Competencies & & & & & & & & & & & $\mathbf{N}+$ & $\mathbf{N}-$ \\
\hline Learning orientation & & + & + & & & + & & & + & + & 5 & 0 \\
\hline Self management & & & + & & + & - & + & & + & & 4 & 1 \\
\hline Planning & + & & & + & & & & + & & & 3 & 0 \\
\hline Market orientation & + & & + & & & - & & & + & & 3 & 1 \\
\hline Result orientation & & + & & & + & & + & & & - & 3 & 1 \\
\hline Networking & & & & & + & & + & & & + & 3 & 0 \\
\hline Leadership & & & & + & & + & & & - & & 2 & 1 \\
\hline Problem analysis & & & & + & & - & & + & & & 2 & 1 \\
\hline Organizing & & & & & & + & & + & & & 2 & 0 \\
\hline Conceptual thinking & & + & & & & & & & & & 1 & 0 \\
\hline Negotiating & + & & & & & & & & & & 1 & 0 \\
\hline Persuasiveness & & & & & & & & & & & 0 & 0 \\
\hline Vision & & & & & & & & & & & 0 & 0 \\
\hline General awareness & - & - & & & & & & & & + & 1 & 2 \\
\hline Management control & & & & & & & & - & & & 0 & 1 \\
\hline Value clarification & & - & & & & & & & & & 0 & 1 \\
\hline Judgement & & & & & & & - & & - & & 0 & 2 \\
\hline Team work & & - & & & - & & & & & & 0 & 2 \\
\hline Strategic orientation & & & - & - & & & & - & & & 0 & 3 \\
\hline HRM/HRD & - & & - & - & - & & - & & & - & 0 & 6 \\
\hline $\begin{array}{l}\text { International } \\
\text { orientation }\end{array}$ & - & & - & - & - & & - & - & - & - & 0 & 8 \\
\hline
\end{tabular}


Table 4. Examples of entrepreneurial learning activities

\begin{tabular}{|c|c|}
\hline Туре & Example \\
\hline $\begin{array}{l}\text { Acquiring knowledge } \\
\text { through training }\end{array}$ & $\begin{array}{l}\text { After following a course in personnel management I have tried keeping official } \\
\text { functioning meetings, but my staff got so stressed by this idea that I decided to do it in } \\
\text { a far more informal way. }\end{array}$ \\
\hline Asking a specific question & $\begin{array}{l}\text { I called my advisor to check what price he would give for buying my neighbour's } \\
\text { company. He gave me a price indication that was } 50.000 \text { Euro below the price I had in } \\
\text { mind. At the end of the day I could buy the company for a much lower price. }\end{array}$ \\
\hline Checking information & $\begin{array}{l}\text { I knew they once wrote a report on the introduction of a new concept that failed; I } \\
\text { looked up all the details and knew that I could not pull off this opportunity all by } \\
\text { myself. }\end{array}$ \\
\hline Conversation & $\begin{array}{l}\text { I once lost two good buyers because I did not know their demands. Now, before the } \\
\text { introduction of a new chain concept, I first talk to my potential clients. }\end{array}$ \\
\hline Discussion & $\begin{array}{l}\text { After being cheated by one of my own employees I discussed this with my other staff, } \\
\text { who argued that I have far too much faith in people, and that I should change my } \\
\text { behaviour and be more strict; I should directly let them pay for things they want. }\end{array}$ \\
\hline Experiment & We are experimenting now with a new marketing concept for potted plants. \\
\hline $\begin{array}{l}\text { Holding on to personal } \\
\text { vision }\end{array}$ & $\begin{array}{l}\text { I never do too much with regard to complying with rules and regulations. I took some } \\
\text { risks with that, but that always outweighed the benefits. }\end{array}$ \\
\hline Observation & $\begin{array}{l}\text { When I was still working as an employee at a firm, I saw that I could do these things } \\
\text { for myself as well, so I decided to start my own firm. }\end{array}$ \\
\hline $\begin{array}{l}\text { Performing occupational } \\
\text { tasks }\end{array}$ & Introducing bit by bit elements to improve employees’ motivation; this works well. \\
\hline Receiving feedback & $\begin{array}{l}\text { We have regular meetings with our large buyers to evaluate what went well and what } \\
\text { went wrong, so that we can do things differently in the future. }\end{array}$ \\
\hline Reflection & $\begin{array}{l}\text { When I manage people they have to understand very fast what I want, often too fast, } \\
\text { because for me it is something automatic, for the others it is not, and I find that } \\
\text { difficult, that's why I stopped managing my staff. }\end{array}$ \\
\hline Replication & $\begin{array}{l}\text { I copied the way colleagues handled staff, but after a few failures I changed the } \\
\text { strategies and now it works. }\end{array}$ \\
\hline
\end{tabular}


Table 5. Frequencies and percentages of learning activities of entrepreneurs mentioned in interviews $(n=10)$

\begin{tabular}{|l|c|c|}
\hline Entrepreneurial learning activity & n & $\mathbf{\%}$ \\
\hline Reflection & 21 & 19.8 \\
\hline Observation & 16 & 15.1 \\
\hline Experimentation & 12 & 11.3 \\
\hline Performing occupational tasks & 11 & 10.4 \\
\hline Checking information & 9 & 8.5 \\
\hline Discussion & 9 & 8.5 \\
\hline Conversation & 6 & 5.7 \\
\hline Receiving feedback & 6 & 5.7 \\
\hline Asking a specific question & 5 & 4.7 \\
\hline Holding onto a personal vision & 4 & 3.8 \\
\hline Replication & 4 & 3.8 \\
\hline Acquiring knowledge through training & 3 & 2.8 \\
\hline & $\mathbf{1 0 6}$ & 100.0 \\
\hline
\end{tabular}


Table 6. Distribution of the learning activities of entrepreneurs by entrepreneurial competence cluster $(n=10)$

\begin{tabular}{|c|c|c|}
\hline Competence cluster & $\mathbf{n}$ & $\%$ \\
\hline Strategic & 28 & 26 \\
\hline Opportunity & 21 & 20 \\
\hline Organizing & 21 & 20 \\
\hline Technical-Occupational ${ }^{*}$ & 19 & 18 \\
\hline Relational & 10 & 9 \\
\hline Commitment & 5 & 5 \\
\hline Conceptual & 2 & 2 \\
\hline Total & $106^{* *}$ & 100 \\
\hline
\end{tabular}

* The cluster technical occupational was added since the Man et al. (2002) clusters do not include a technicaloccupational (the entrepreneur as craftsman) component.

${ }^{* *}$ Seven learning activities were scored under two competence clusters. 